\title{
Islam and Democracy in Contemporary Politics in Indonesia: Contributions and Model
}

\author{
Warjio $^{1}$, Heri Kusmanto ${ }^{2}$ \\ \{warjio1974@gmail.com ${ }^{1}$ \} \\ North Sumatra University, Indonesia ${ }^{1,2}$
}

\begin{abstract}
The relationship of Islam with democracy emerged as a political issue that most often cause debate. In a society where religion has become a symbol of identity, the way a liberal democracy must pass through the doors of religious politics. The democratization process thus cannot be artificially separated from the discourse surrounding the normative rules of religion in government. On the other hand, democracy does not require the privatization of religion, but it requires a reinterpretation of religious ideas that are more conducive to democracy. Democracy does not always require the rejection or the privatization of religion. But clearly, they require a reinterpretation of religious ideas with respect to the basis of moral and political authority and individual rights are valid. The presence of Islamic politics, especially in public spaces is an important part of the process of reinterpretation of democratic discourse. With this reinterpretation, Islamic political groups will play an important role in the growth and consolidation of democracy. Indonesia, as a Muslim-majority country, the relationship of Islam with democratic political debate often appears in the reinterpretation of religious ideas that are more conducive to democracy. In this contex, this paper will explore contribution and model Islam and democracy in Indonesian political contemporary from New Order to Reform Order.
\end{abstract}

Keywords: Contribution, Democracy, Islam, Model, Religious Movement.

\section{Introduction}

Many scholars studying Islamic affairs with politics still conclude that when Islam is fought in politics will always be a threat and always fail. The Huntington thesis (2005) on the collision of Western civilization with Islam in the future of world politics gives an impression that political Islam will have many problems [1]. Huntington's thesis (2005) views the negative role of Islam in politics and makes it a world threat. But Huntington is not the only scholar who views the negative position of Islam in politics[1].

Many other scholars have the same view as Huntington. Among them are Donohue and Esposito (1994) [2]. The two scholars questioned in modern times whether Islam is still capable of meeting the needs of modern life in politics, social and economics? Oliver Roy [3] through his work entitled The Failure of Political Islam, which has been widely seen, has written Islamic movements in politics he called the Islamic Movement has lost its strength. Islamism has transformed itself into 
a "social democrat" movement. It no longer offers a different model of society or a brighter future. Today Islamist political victories in Muslim countries only bring about changes in law and customs only. Recent Islamism has transformed into a neofundamentalism model that only cares for shari'a enforcement, without creating new forms of politics.

In other words, Islamism is destined to serve as a veil only for unsuccessful political lojik. Lojik which in the end we see the traditional division of ethnicity, tribe or group. From such reality, Fazlur Rahman (1998: 140) [4] , believes that the inclusion of politics into the religious domain has been detrimental. According to him Islam's teachings should be a political guide, but what happens is the exploitation of Islamic concepts and organizations by political groups and elites.

Scholars focusing on democratic transition studies such as O'Donnel and Schmitter (1993) [5] define the transition as a time interval between the political regime and the other. The transition on one side is marked by the commencement of the split process of an authoritarian regime. On the other hand, marked the acceptance of some form of authoritarian empire or the emergence of an alternative revolution. Thus, the end of democratic transition process is not always one and does not always come from democracy. Because the views on democracy are very complex [6]. Thus Rabasa \& Chalk mentions that the transition period of democracy is a very critical time (2001). Inoguchi (1998) [6] mentions that critical times arise because the transition of democracy is actually seeking the actual form adapted to the needs and the place where the process takes place. Therefore, it is necessary to raise the culture and encouragement towards improvement from society and not from the country. Movements from civil society become indispensable to support the transition process of democracy. Therefore, civil society needs to consolidate democracy [5].The question is, civil society and organizations are hard to deal with as many of them take advantage and are considered part of the political euphoria.

In order for the transition process to democracy, Huntington (1997)[7] mentions three alternative ways, namely transformation, change, and negotiation. In many recent democracies the process of democratic negotiations is the result of joint action of the empire and opposition. In the kingdom there is a balance between conservative groups and reformers in such a way that the government is willing to negotiate but is unwilling to initiate regime change. While on the part of the opposition, a democratic moderate group is strong enough to control the anti-democratic radical groups, but they are not strong enough to overthrow the empire. Therefore, they are better off choosing diplomacy.

In parallel with Huntington's (1997)[7] statement, Jean Blondel (1998) [8] asserted that democratic transition would succeed in forming a consolidation of democracy if equality and freedom were given place and guaranteed in legislation. The similarity and freedom can be created in the form of political parties and court empowerment.

\section{Indonesian Islamic Politic Experience's Contemporary on Democracy: Contribution and Model}

\subsection{A Problem of Contribution}


In the case of Indonesia, history has given important lessons that political preaching or part of a political struggle has always been a failure. The case of the Islamic State of Indonesia-Indonesian Islamic Army (DI-TII) by Kartosuwiryo (1949) which was later crippled with weapons by the government during the time of Soekarno has clearly shown that political Islam did not get the right place in Indonesia's political arena. Even as Indonesia's democratic stage was held in the first general election in Indonesia, in 1955, the presence of Masyumi's Islamic political party in politics, by President Soekarno was considered a threat. In this regard Katimin (2007) study, Aminuddin (1999)[9], Warjio (2005)[10] has shown this situation.

As shown by Aminuddin (1999)[9], the Old Order under the leadership of President Soekarno the power of Islamic parties that fought for da'wah and Islamic values were crippled and destroyed. The reason is, Islamic parties like Masyumi will only be a barrier in the development process. When the Old Order was demolished and replaced by the New Order (1966) under the leadership of Soeharto, the New Order of the New Order of the New Order, the Development Unity Party (PPP) [11] and the Islamic struggle in politics was also destroyed. [10] Whereas the Old Order shift to the New Order for the help and support of elites and Muslims.

As the study of Aminuddin (1999)[9], Warjio (2005)[10] Ahmad Syafii Maarif (1984) political position towards the end of the Guided Democracy (1959) and the transition from the Old Order to the New Order, the political power of Islam emerged as the main partner of the Armed Forces of the Republic of Indonesia ) to destroy the Indonesian Communist Party (PKI) and its supporters in which President Soekarno's leadership took place. The role of the Muslim ummah as the most important and crucial perpetrator in the PKI's devastating alliance, among others, shows that almost all the strengths of Islam such as the Student Action Union (KAP Gestapu) of the Indonesian Students Action Union (KAMI), the Indonesian Student Action Unions (KAPI) whose leaders are held by figures Islamic organization. The military partnership with Islamic political power continued after the PKI was disbanded and at the same time managed to bring down President Soekarno. The hope of mounting Islamic ummah to the New Order so that they can play a role in the development process of the New Order after the Old Order collapsed and only hope.

The New Order policy to reduce the political role of the people through the narrowing of the space of political party movements by simplifying political parties is only three; Indonesian Democratic Party (PDI); The Association of Developmental Unions (PPPs) and the Golkar and the marginalization of the ideological role, which makes Pancasila as the only national ideology clearly opposed to the spirit of the partisan of the political elite of Islam. The question of weakening the ideology of political parties and the reduction of political parties is the question and strategy applied by the New Order to undermine the power of the Muslim ummah in politics.

Another issue that was also used in the New Order was the adoption of policies related to public service such as marriage bill (1973), gambling issues (Porkas), Social Fund Contribution, Social Fund Contribution Gift (SDSB), Flow of Trust in the Line The State General Assembly (GBHN), the General Assembly of the People's Consultative Assembly (MPR 1978), the ban on school holidays in Ramadan and so on. In other words, between the New Order regime's strata and the political strength of Islam, it is in fact reversed. That is, when the New Order regime tried to restrict the political arena by narrowing the political role of society by limiting the space of political party movements, most of the Islamic groups were concerned with the political interests of the ummah through the path of Islamic political parties. Some remain in other ways like following the New Order political arbitration [9]. 
The dynamism of the Muslim ummah in relation to the New Order state in the early 1970s which was stained with tensions and confrontations put the position of the Muslims into marginalized in the New Order political process, compared to other groups like Christian (Abdurrahman Wahid, 1999). Various strategies implemented by PPP and other Islamic opposition groups at the time resulted in the increasingly marginalized Muslims. Such political fact is a problem that must be solved by Islamic intellectuals in particular. This situation created a state of affairs in the New Order period always in the confines and spells that resulted in the attempt to realize the full identity of Islam was not so successful.

The political dynamics are centered on a clear direction, namely the upholding of democracy. After the passing of the New Order re-emerged the new spirit and hope for the people of democracy. This was due to more than three decades under the supervision of two authoritarian regimes, namely Soekarno (1959-1966) and Soeharto (1966-1998). The emergence of student demonstrations during the middle of 1997 and 1998 was the clearest indication of this desire.

This hope as mentioned by Syamsuddin Haris [12] is actually an old dream. However, both during the reign of Soekarno and Suharto, the Indonesian people believed that democracy could be postponed if there were more urgent interests. Soekarno with his 'nation building', and Soeharto with his 'economic growth', apparently delayed it. Therefore, Indonesia's history shows that democracy has never really happened during the two regimes, despite reasonable arguments (Munafrizal Manan, 2005).

Past political trauma has created awareness that democracy is a bargaining option if it does not want to repeat the emergence of authoritarian regimes in Indonesia. This is why, the people who support democracy really want the transition to democracy that is being pursued to succeed.

If referring to the concept of Dahl (2001), democratic means the process of change of the authoritarian regime. Such a process of change often does not provide space for participation and political freedom. In many concepts, democratic processes are generally divided into four phases that relate to each other, namely freedom, transition, installation and consolidation.

\subsection{A New Model of Democracy: The Role of Middle Class}

What the scholars say about the democratic transition that emphasizes on the structural, strategic, constitutional or political-economic options set out above, particularly in the Asian context has been criticized. Such methods are considered inadequate to explain the question of the democratic transition in Asia.

In this regard, Guo Sujian (1999) explains that structural approaches can help explain the regime's rule but cannot explain how elites make changes. While the strategy approach is a very elite and non-rooted model. Because there are many cases, the transition of democracy is rooted not to the elites. Obviously, the method of choice strategy is inadequate in analyzing the transition process towards consolidation of democracy. This statement is also in line with the constitution. According to Guo Sujian (1999), it does not necessarily mean that the transition of democracy is rooted in the constitution, but it can come from mass movements.

What was conveyed by Sujian Guo (1999) is in line with what Munafrizal Manan (2005) conveys. Munafrizal Manan (2005) assesses that controlled democracy will be achieved if the criteria for democratic procedures are upright and all groups politically accept the existence of existing democratic political institutions and rules. Democracy procedure is the minimum 
prerequisite for controlled democracy, but the transition to democracy procedure also does not guarantee the stability of democracy (Munafrizal Manan, 2005).

Controlled democracy will survive when political attitudes are conducive to both the elite and the masses. The elites should be able to build together on political rules and political constitutions and alter the split between them into unity through agreement and elite togetherness. While the masses must have great political participation in the electoral process and other political constitutions to uphold the democracy of the procedure. So, the space for massive mass violence or coup d'etat and other means of coercion will be closed (Munafrizal Manan, 2005).

Such a situation raises many questions as to why the Muslim ummah should be suspected in New Order politics? Why do Muslims in the process of building the New Order? What is the attitude of the Muslims under the New Order on the modernization of the New Order? These are some of the issues that arise and should be solved. In such a situation came a model of "new thinking" brought by Islamic intellectuals. They generally think radical changes must be made to answer questions about the position of the Muslim ummah in the New Order.

This new mindset not only addresses the position of the Muslim ummah in the New Order political arena but also discusses God, man and society, especially those relating to the political affairs of the ummah and to breakthroughs to restore the psychological mobility of the ummah. In subsequent developments as stated by Bahtiar Effendy (1995)[13] brings three implications: (1) formulating the fundamental political theological principles; (2) redefining Islamic ideals; and (3) reviewing Islamic political strategies. It is true that Soeharto's New Order regime had played a crucial role in changing Muslim political attitudes. The shift, however, is not only due to Soeharto who ruled the country repressively, but also due to the long and passionate role played by Muslim intellectuals. What is happening in Indonesia is not happening in Egypt and other Middle Eastern countries. Indonesian intellectuals played an important role in changing Muslim political mindset and attitude.Through lectures, writings, and actions, they advocated democracy and delegitimized Islamic parties. Unlike in Egypt and other Middle Eastern countries, the Indonesian reform movement has always been through organizations. Intellectuals such as Abdurrahman Wahid (19402009), Ahmad Syafii Maarif (born 1935) and Nurcholish Madjid (1939-2005) are Muslim leaders who chaired big organizations.They spread their liberal ideas to Muslim society through these organizations. Wahid did it through Nahdlatul Ulama (40 million members), Maarif through Muhammadiyah (30 million members), and Madjid through Islamic Student Association and its alumnae (over 10 million members).

In Egypt, the Islamic reform movement has developed in a more solitary manner. Great intellectuals such as Jamaluddin al-Afghani (1837-1897) and Muhammad Abduh (1849-1905) did not have any organization where they could spread their ideas. This trend continues until today's generation of reformers. Intellectuals such as Hassan Hanafi (born 1935) and Nasr Hamed Abu Zayd (1943-2010) are solitary thinkers who do not have big followers. They disseminated their ideas in academic classes, seminars, and scholarly journals. No matter how sophisticated their ideas are, they remain limited and never reached to the grass roots.

The idea of this "new model" according to Amiruddin (1999: 143) arose from the idea of Nurcholish Madjid. Nurcholish Madjid's idea is more empirical and innovative. One of the empirical and reformist Nurcholish Madjid ideas is to immediately replace the ideological tendencies of political parties (Islam) and not to drown with old patterns [14]. 
Nurcholish Madjid (1987) [14] criticized Muslim leaders at that time who purely instituted institutions such as: Islamic parties; Islamic ideology and Islamic state idea. In Nurcholish Madjid (1987: 205) [14] Islamic political parties, Islamic ideology or Islamic state is not something sacred as the Qur'an itself does not order the formation of such an Islamic Party, Islamic State. The only holy is Allah SWT. In this frame of mind this is Nurcholish Madjid calling for "Islam Yes, Islamic Party No"[14]. A call is made to encourage Muslims to direct their commitment to Islamic values and not institutions such as Islamic parties. This Nurcholish thought is based on the idea that political behavior and Islamic utilization in Islamic parties will only bring down the true values of Islamic teachings. The distrust of the effectiveness of the political struggle of the ummah through the Islamic party is a common symptom among the "new thinking" movement [9].

Although the Nurcholish Madjid [14](Dedy Djamaluddin Malik \& Idi Subandy Ibrahim, 1998), especially by the political elite of the Party of Islam and its non-partisan opposition, in the sense of New Order's political practice this situation actually simplifies the New Order to smoothen its political process of marginalizing the role of Islamic politics, PPP during the New Order era. Implication, PPP not only did not get much time during the New Order in every election, PPP's timelapse to be able to apply Islamic identity in the broader sense of da'wah in New Order politics became narrow. Golkar as a New Order political party as a result of declining PPP roles is getting stronger as supported by the bureaucracy and the military.

The failure of the Islamic political party during the Old Order under the umbrella of President Soekarno and the New Order under President Suharto clearly reveals the true face of the failure of Islamic political parties in Indonesia in carrying out their duties (dakwahnya). The unity of religion and politics that is the identity of the Islamic party is still suspect and has not been given the right place

In the theoretical view, authoritative scholars and references to many Muslim ummah like Yusuf Al-Qaradhawi (2008)[15] also consider the separation of religious and political thinking in understanding the above issues. This situation is deliberately exchanged by secularists by changing the relationship between state and religion in accordance with the theory they apply. They separate politics from religion and separate religion from the state. They also popularize no religion in the country and no country in the religion. They consider that religion is a matter of personal nature. Religion is only seen as a ritual following certain interests, party interests, group interests or other short-term goals.Repositioning religion in politics in the view of Yusuf Qaradhawi is very important. The view as delivered by Yusuf Qaradhawi later received the Muslim community's response to recall Islam's position in politics.

But the question is, does not cease to matter in Islam and politics. Today, when the da'wah begins to come into contact with practical political activity, it will and will surely face the democratic system; a system that is questionable when it comes to vis a vis with Islam as the ideology of the ummah [16] (Abdul Hadi Awang, 2007; Sohirin Mohammad Solihin, 2006).

The apriori attitude posed by the West arose as there was a fundamental difference between the concept of secular democracy and the concept of Islamic politics, which lies in the view of sovereign holders in relation to the nature of democracy. The concept of secular democracy gives sovereignty to the people, so they say that sovereignty is in the hands of the people because the people's voice is God's voice. While in the Islamic concept of sovereignty it is entirely in the hands of God. God's voice must be the voice of the people. In practice, the law in secular democracy is a 
common consensus note produced through the constitution, while in Islamic law it is natural and is a constitutional task to realize it [16].

The distinction posed by the demolition of the democratic system is fundamental; about the real understanding of democracy [16] (Yusuf Qaradhawi, 2008). But a question to be contemplated is whether there is no point between Islam (as a principle and ideology) and democracy (as a reality that is facing the ummah of Muslims), which will later become the way for the ummah to reflect on his political will or more than to enforce it dakwah in indonesia?.

There is a presumption today that the ummah of Islam suffered a setback and defeat in all aspects of life, especially in politics. Whereas the political field is part of Islamic teachings. On the other hand, politics is a very strategic part of organizing and putting Muslims in power. When the Muslim ummah of a majority of the country of Indonesia have not been able to accept the reality of the Western political system (democracy) and still rely on the ideal of the Islamic political system then the Muslim ummah will be defeated in today's political world. Therefore, the ummah must be open to discourses, coming from the outside (West) then analyzed and considered good and bad and find the intersection between these two different concepts (Islam and democracy).

The meeting point is due to participation. This concept gives a strong position to society based on the values of freedom and human rights. This intersection between democracy and Islam is what gives birth to empowerment and gives space to the ummah. So, this gives an opportunity for the ummah to realize the benefits of the ummah by doing da'wah (Anis Matta, 2007: 21).

The basis of democratic efforts in Indonesia goes unnoticed without going through the stages as suggested by Dahl (1992). In the beginning, democratic supporters sought to formulate the constitution to limit the power of the former President. Then build a multi-party system. Unleash the use of ideology except communism. Changing Parliament becomes stronger. Holding independent General Elections and supporting freedom of press and journalists. This change does not work as it should be but limited by the political behavior of society. This is because democracy also requires a change in the behavior of the community, as Schmitter (1998) once described about the importance of reinforcing the political culture of democracy [5].

The question is, which groups of people play a major role in making changes to fill the transition of democracy? According to many scholars such as Harold Crouch (2001), Takashi Shiraishi (2001), Tamario C. Rivera (2001) Hing Ai Yun (2001), Alfred L. Oehlers (2001), Rajah Rasiah (2001), the transition of democracy is always mobilized and filled by middle class groups [17],[18],[19],[20][21]. These people take on an important role in how changes are shaped and directed.

In the case of Indonesia, as mentioned by Sohirin Mohammad Solihin (2006) [22], Muslims in particular Islamic intellectuals and Islamic organizations have played an important role in the process of democratic transition and the filling of the democratic transition. Sobirin Muhammad Solihin (2006) argues that the intellectuals and Islamic organizations necessarily take on their role and part to fill the process of political transition. It is also because of the many interests outside the people and Islamic organizations that will also take on the role.

This is all about the future of Indonesia, the majority of whom are Muslims. It means that if Muslims, especially intellectuals and Islamic organizations, do not take a role, it will be taken by other people. However, Islamic intellectuals such as Amien Rais, Indonesian Islamic Da'wah Council (DDII), tarbiah movement, including Islamic students are very active in the process of political transition in Indonesia. What is said by Sobirin Muhammad Solihin (2006), such an 
Indonesian context is clarified or that the Islamic middle class in Indonesia also plays a strong role in the process of democratic transition (Sharifah Zaleha Syed Hassan, 2001). They played a crucial role in enlightening Indonesian Muslims. Through mass media, discussion forums, public lectures, and social actions, they spread their flexible interpretations of Islam and appealed Muslims to fully engage with modern challenges.

\section{Conclusion}

I have analyzed the given piece of literature to prove that the democracy is changing in our politics. In Indonesian Islamic politics contemporary cases, democracy moved from New Order to Reform Order. In the process of democracy transition in Indonesia Islamic middle class (middle class) Islam plays a role in the process of seeking and reinforcing their identity especially taking part in political participation. Indonesian democracy is still young, but it is growing dynamically. Despite many problems that Indonesian government has to face, the country can successfully keep its economic growth, curbing the unemployment rate, reforming legal system, and building infrastructure. Since 1998, Indonesia has undergone three general elections, which were consecutively won by secular (non-religious) parties, namely Indonesian Democratic Party (1999), Golkar (2004), and Democratic Party (2009). In Indonesia, Muslim intellectuals have been very active in promoting democracy and pluralism to Muslim societies. Abdurrahman Wahid was one of the most influential leaders among the Nahdlatul Ulama members. Born in a strong family background and educated in Baghdad and Cairo, Wahid was highly respected by both Muslims and non-Muslims in the country. He read Western literatures and tried to synthesize them with Islamic intellectual tradition.

\subsection{Acknowledgement}

This research was supported/ by Universitas Sumatera Utara (USU)]. I thank our colleagues from TALENTA USU who provided insight and expertise that greatly assisted the research, although they may not agree with all of the interpretations/conclusions of this paper. I thank Prof. Dr. Muhammad Syukri Salleh, Prof. Dr. Subhilhar, MA, Prof. Dr. Arif Nasution, MA, Dr. Heri Kusmanto for comments that greatly improved the manuscript. I am also immensely grateful to Cahyo Seftyono bin Harno for their comments on an earlier version of the manuscript, although any errors are our own and should not tarnish the reputations of these esteemed persons.

\section{References}

[1] S. P. Huntington, "Benturan antar Peradaban dan Masa Depan Politik Dunia (The Clash of Civilization and the Remaking of World Order)(Indonesian Translation, the 9 Edition)," Yogyakarta: Penerbit Qalam, 2005.

[2] J. J. Donohue, Islam dan Pembaharuan. Jakarta: RajaGrafindo, 1984.

[3] O. Roy, Gagalnya Politik Islam. Jakarta: Serambi, 1999.

[4] J. O. Voll, "Fazlur Rahman. Islam and Modernity: Transformation of an Intellectual Tradition. 
Chicago: University of Chicago Press, 1982. 172 pages, index. \$15.00,” Rev. Middle East Stud., vol. 17, no. 2, pp. 192-193, 1983.

[5] O. \& Schmitter, Transisi Menuju Demokrasi: Rangkaian Kemungkinan dan Ketidakpastian. Jakarta: LP3ES, 1993.

[6] \& J. K. Takasih Inoguchi, Edward Newman, The Changing Nature of Democracy. United State: National University Press, 1998.

[7] P. Samuel, "Huntington. Gelombang Demokratisasi ketiga," Jakarta. Graf., 1997.

[8] J. Blondel, "Democracy and Constitutional," 1998.

[9] Aminuddin, Kekuatan Islam dan Pergulatan Kekuasaan di Indonesia: Sebelum dan Sesudah Runtuhnya Rezim Seharto. Yogyakarta: Pustaka Pelajar, 1999.

[10] Warjio, "Perjuangan Ideologi Dua Parti Politik Islam: Kes Kajian Masyumi (Indonesia) dan PAS (Malaysia) 1945-1969," 2005.

[11] S. Haris, PPP dan Orde Baru. Jakarta: PT Gramedia, 1981.

[12] S. Haris, Konflik presiden-DPR dan dilema transisi demokrasi di Indonesia. Grafiti, 2007.

[13] B. Effendy, Islam dan Negara-Transformasi Gagasan dan Praktik Politik Islam di Indonesia, Democracy Project, 2011: Islam dan Negara-Transformasi Gagasan dan Praktik Politik Islam di Indonesia, vol. 1. Bukupedia, 2011.

[14] N. Madjid, "Islam dan Kemodernan dan Keindonesiaan," Bandung: Mizan, 1987.

[15] Y. Al-Qhardawi, "Meluruskan Dikotomi Agama \& Politik 'Bantahan Tuntas Terhadap Sekularisme dan Liberalisme," Jakarta: Pustaka al-Kautsar, 2008.

[16] N. Fahmi, Menegakkan syariat Islam ala PKS. Era Intermedia, 2006.

[17] H. Crouc, "The Perils of Prediction: Understanding The Indonesia Transtition," 2001.

[18] T. Shiraishi, "The Moral Foundation of The Indonesia State," 2001.

[19] H. A. Yun, "Reconstituting the Middle Classes: Teachers, the Evaluative State and the Market in Singapore," Pp. < Inser. page numbers here>, Southeast Asian Middle Classes, Prospect. Soc. Chang. Democr. Ed. by Abdul R Ambong. Kuala Lumpur Univ. Kebangs. Malaysia, 2001.

[20] A. L. Oehlers, "Singapore's Middle Class and the Prospects for Democratisation into the 21st Century'," Southeast Asian middle classes Prospect. Soc. Chang. Democr. Bangi Penerbit Univ. Kebangs. Malaysia, Malaysian Int. Stud. Ser., pp. 192-207, 2001.

[21] R. Rasiah, "The political economy of the southeast Asian financial crisis," Southeast Asian Middle Classes Prospect. Soc. Chang. Democr., pp. 46-79, 2001.

[22] S. M. Solihin, Islam and Politics: Emergence of Reformative Movement in Indonesia. Pusat Penyelidikan, Universiti Islam Antarabangsa, Malaysiac2006., 2006. 